\title{
Career Preparation and the Political Science Major: Evidence from Departments
}

Todd A. Collins, Western Carolina University

H. Gibbs Knotts, Western Carolina University

Jen Schiff, Western Carolina University

ABSTRACT We know little about the amount of career preparation offered to students in political science departments. This lack of information is particularly troubling given the state of the current job market and the growth of applied degree programs on university campuses. To address this issue, this article presents the results of a December 2010 survey of 279 political science department chairs that asked questions about the level of career preparation in their respective departments. Based on our empirical findings, we believe that political science departments are not doing enough to address their students' career preparation. Our results demonstrate that most departments rely on voluntary internships and faculty advisers to address career-related issues for political science majors. Only a few departments use required internships, required resumes, specific classes related to career preparation, and social media sites such as Facebook and LinkedIn to support career preparation. We also found substantial differences in career preparation across department type (BA, MA, and $\mathrm{PhD}$ ) and between public and private universities, urban and rural universities, and universities with different average SAT scores. Our findings should interest faculty and administrators who are concerned with different approaches to career preparation on college campuses.

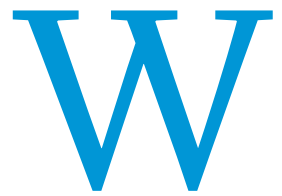

hat can you do with a political science degree? Political scientists regularly grapple with this question, which is posed by students and parents alike. Indeed, some people outside the discipline criticize political science for producing majors with little earning potential and few career options (Breuning, Parker, and Ishiyama 2001). Those who are within the discipline often respond by stressing that political science, like other liberal arts majors, helps develop core learning outcomes such as "knowledge of human cultures and the natural and physical world, intellectual and practical skills, individual and social

Todd A. Collins is assistant professor of political science and public affairs and interim public policy institute director at Western Carolina University. He can be reached at tcollins@wcu.edu.

H. Gibbs Knotts is professor political science and public affairs and interim dean of arts and sciences at Western Carolina University. He can be reached at gknotts@wcu.edu. Jen Schiff is assistant professor of political science and public affairs at Western Carolina University. She can be reached at jsschiff@wcu.edu. responsibilities, and integrative learning" (Humphreys 2006, 3). Other political scientists argue the importance of imparting intellectual skills as students should develop "critical and analytical faculties" (Mansfield 1947, 506). Political science professors also emphasize how well the degree prepares students to be lifelong learners and effective citizens (Breuning, Parker, and Ishiyama 2001).

As for particular careers, political science professors may talk about how well the major prepares students for postgraduate studies. Graduate school in political science is an obvious choice, and political science professors have real experience when it comes to getting into and succeeding in graduate school. Law school is another popular option for political science majors and, not surprisingly, many departments have prelaw advisers dedicated to helping students establish a strong foundation for a legal career. Professors are also likely to highlight other career options for political science majors including government work, international careers, business jobs, and work in the nonprofit sector. 
Instructors and advisers may also refer students to the American Political Science Association's (2003) publication, Careers and the Study of Political Science. This guide was written in 1974 under the leadership of Mary H. Curzan and is now in its sixth printing with more than 325,000 copies distributed in the first five editions (American Political Science Association 2003).

Yet, this information may leave some pragmatists, including political leaders, asking, "Is this enough?" Some public universities, particularly those with a traditional liberal arts focus, report being the target for larger budget cuts than colleges with a more technical or vocational focus (Morelli 2011). As Maryland governor Martin O'Malley recently stated, "Innovation. Education. College completion. At the end of the day, it's all about job creation and job retention" (Conklin 2011).

In this article, we present the results of a survey of political science department chairs that asked questions about the level of career preparation in their respective departments. We also compare our results from across different types of universities and across three types of political science departments, BA, MA, and $\mathrm{PhD}$ granting units.

\section{POLITICAL SCIENCE CURRICULA CHANGES}

Examining what we teach and how we teach it is not a new topic in political science. Since its inception as a discipline, political scientists have struggled with the problem of "what to learn and how to learn in the area of principle interest" (Mansfield 1947, 501). Commissions from the 1940s suggested highly structured curricula, including training for "practical professions" (Ishiyama, Breuning, and Lopez 2006, 663). In 1951, an American Political Science Association report highlighted three broad goals of the political science major: "education for citizenship, education for public service, and a correction of a woeful public ignorance of international relations" (Wahlke 1991, 49).

In a second major report, published nearly 40 years later, the "Task Force on the Political Science Major" stated that the primary goal of a political science degree should be to "maximize students' capacity to analyze and interpret the significance and dynamics of political events and governmental processes" (Wahlke 1991, 49). This Task Force developed 12 specific recommendations and concluded by noting that the political science major "should be neither a preprofessional program to train political scientists nor a program to produce 'good citizens' ... it should aim at turning politically interested and concerned students, whatever their career plans or their other interests, into politically literate college graduates" (Wahlke 1991, 50).

Subsequent examinations, however, have shown that after many years the Task Force recommendations have not been widely implemented (Ishiyama 2005). Although the report contains few detailed recommendations, the lack of implementation is surprising as many of the suggestions from the 1991 report have been circulating since the 1920s (Ishiyama, Breuning, and Lopez 2006). Some people have suggested that faculty have little incentive to implement some recommendations because engaging in activities, such as civic education, "will not help you get hired, tenured, or promoted" (Leonard 1999, 749). While the discipline's dedicated shift toward more scientific applications and greater emphasis on original research has likely increased undergraduate exposure to marketable skills, such as empirical research methods and statistical analysis, this research focus has perhaps placed strains on the teaching, advising, and career preparation duties of instructors (Ishiyama, Breuning, and Lopez 2006). Others note that some faculty have reservations about techniques other than classroom lectures, believing that these activities, such as internships or experiential learning, are not as effective as traditional methods (Parilla and Hesser 1998).

Although curricula issues have been debated within the discipline, career preparation is seldom discussed. Sociologists have increased career training and have noted the successes of required internships (Danzger 1988), but little is known about what political science departments are doing to prepare their students for the job market. Some political science departments have implemented required senior projects (Breuning, Parker, and Ishiyama 2001), and we suspect that other departments may have specific classes devoted to career building skills, such as resume preparation, portfolios, interviewing skills, or other professional activities. Other departments may implement mentoring programs or foster alumni relationships to build connections with potential employers.

Recent studies have examined some aspects of curricula changes (Ishiyama and Hartlaub 2003; Ishiyama 2005), however, we know little about whether departments address career preparation. We need to look more systematically at the ways departments are (and are not) emphasizing career preparation for undergraduate political science majors. Our study is guided by four key research questions. First, is career preparation part of the curriculum in political science departments? Second, what is the level of careerfocused advising taking place in political science departments? Third, are departments using social media to help students with career preparation? Fourth, what specific factors make some departments more likely to implement career preparation practices than other political science departments?

\section{DATA AND METHODS}

As mentioned above, in December 2010 we conducted a webbased survey of political science department chairs to address our primary research questions. ${ }^{1}$ We sent surveys to department chairs listed in the online version of the American Political Science Association's Directory of Political Science Faculty and Programs. We included department chairs from three types of APSA defined departments: PhD departments, MA departments, and BA separate departments. We opted not to include BA combined departments (departments with both political science and another discipline) because we wanted to focus specifically on political science career preparation. Our final mailing list included 791 total department chairs. These departments included 139 in $\mathrm{PhD}$ departments (18\%), 159 in MA departments (20\%), and 493 in BA separate departments (62\%). We sent an initial email on December 1, 2010 and two follow-up emails requesting completion of the survey. Overall, the survey was sent to 781 valid email addresses and we received 279 completions for a total response rate of $36 \%$. The responding departments included $45 \mathrm{PhD}$ departments (16\%), 58 MA departments (21\%), and 177 BA departments (63\%), which closely resembles the institutional percentages for the entire population. The survey included 24 questions asking the department chairs about career preparation activities in their respective departments.

\section{FINDINGS}

To begin, we asked department chairs a series of questions about the political science curriculum in their units. Figure 1 displays 
Figure 1

\section{Career Preparation in Political Science Departments}

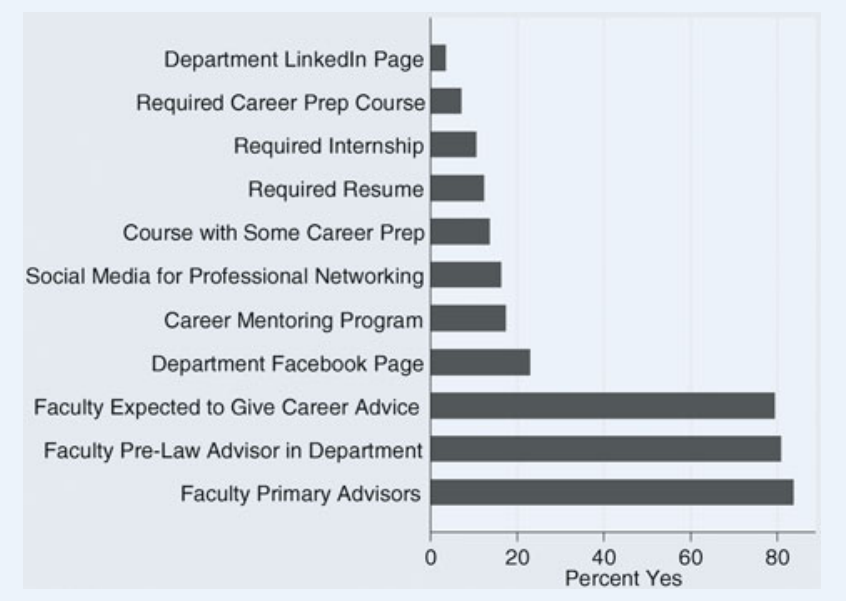

Source: December 2010 Survey of Department Chairs, N varies from 248 to 267

the percent of department chairs answering "yes" to all of our career related question. Few department chairs $(7 \%)$ had a required political science class with the major focus on career preparation. At some institutions, seniors are required to take a senior seminar or portfolio course to help students explore career options, work on resumes and cover letters, and focus on job search and job interviewing skills. Our survey results indicated that it was more common for political science departments to include a course with some career preparation. We found that $14 \%$ of respondents had a required course with at least some portion of the class focused on career preparation. For example, seniors at Bemidji State University are required to take "Thesis and Career Preparation." Independent of a specific course, we also wanted to know whether political science departments required students to complete a resume. According to our survey, $12 \%$ of department chairs indicated that their political science majors were required to complete a resume.

We also wanted to know about internship opportunities in political science departments. Internships can help students apply knowledge learned in courses, acquire new knowledge, and connect in-class and out-of-class experiences (Parilla and Hesser 1998). According to our results, $10 \%$ of department chairs indicated that an internship was required to graduate with a political science degree. We also wanted to find out the percentage of departments that allowed course credit for an internship. Not surprisingly, we found that this was much more common. Almost all of the department chairs surveyed $(97 \%)$ indicated that a political science major could receive academic credit for an internship. This percentage was much higher than a 1970 study indicating that $65 \%$ of sociology departments offered an internship option (Satariano and Rogers 1979).

In addition to career-focused curriculum, we also examined the extent of career-focused advising in political science departments. In the past, some people have suggested that advising may be important to assess "the student's previous training, creative capacity, range of interests, and future intentions" (Mansfield 1947, 505). First, we wanted to know the percentage of political science departments with faculty as the primary academic advisers.
According to our survey, $84 \%$ of department chairs indicated that professors were the primary academic advisers for political science majors. In $11 \%$ of departments, professional academic advisers did the advising and $5 \%$ of department chairs said that advising was provided by someone other than a professor or professional academic adviser. Not only do professors provide the majority of advising, we found that department chairs expect their faculty to provide career-related advice. According to our survey results, $80 \%$ of department chairs said that they expected their faculty to provide career advising.

We also asked department chairs about two other types of careerfocused advising. As mentioned above, law school is a popular option for political science majors so we asked department chairs whether they had a faculty member who serves as a pre-law adviser for political science students. We discovered that $81 \%$ of department chairs have a pre-law adviser for political science students.

Indeed, the answers to our survey's open-ended questions further support these findings, suggesting that political science students with specific career-related major concentrations, such as prelaw, public policy, or secondary education, receive more guidance in terms of career advising than majors who have no particular concentration. One department chair wrote that, at his/her university, the majors with the more specific concentrations receive extensive career advice because they have "a common focus," while the department does not "do much" for its "standard majors." Several of our surveyed departments also use extracurricular clubs (such as the pre-law or public administration club) to provide additional career guidance to these more specialized majors. These opportunities are important as well because prior research notes the significance of out-of-class experiences, such as student clubs and leadership roles in extracurricular activities, help facilitate students' personal and intellectual growth (Kuh 1995). Many political science departments also use graduate school advising to help fill the role of career preparation, and several departments have an adviser dedicated to preparing students for graduate school. Our findings also suggest that some departments encourage their students to attend graduate school as the primary postgraduation option.

In terms of advising, we wanted to know whether departments had career mentoring programs. Mentors can provide important benefits to students including career advancement, networking, professional development, and personal identity (Wright and Wright 1987). Some departments seem to recognize and accept the value of mentoring-we found that $17 \%$ of department chairs indicated that they had a career-mentoring program to connect current students to working professionals.

Given the growing importance of the Internet for career preparation, we asked a series of questions about the use of social media in political science departments. As one personal branding expert noted, "If you aren't actively involved in social networks, you will be at a competitive disadvantage in both being recruited professionally and interfacing with your friends, family, fellow employees, and potential key contacts" (Schawbel 2009, 149). First, we asked about Facebook, a social networking site that started on the Harvard campus and that according to the company has more than 800 million active users. We discovered that $23 \%$ of political science departments have a presence on Facebook. We also included a question about LinkedIn, a social networking site for career professionals that reports more than 135 million members. We found that few departments (3\%) had a presence on LinkedIn. Regardless of which site they used, we 
found that $16 \%$ of department chairs reported using social media websites to connect current students to working professionals.

The majority of department chairs that responded to openended questions, however, did not indicate that social networking was central to their departments' career preparation model. The two participants who did mention social networking spoke about it tangentially and only in relation to the efforts of their university's alumni association and career services office. Instead, the APSA publication, Careers and the Study of Political Science (2003) proved a more popular career preparation tool, as $9 \%$ of our open-ended responses indicated that their departments give each undergraduate a copy of this publication on declaration of the political science major. For several department chairs, this publication was the only stated means of student career preparation on which they wished to comment in their open-ended responses.

Finally, and as a sign of the strained fiscal times in which most modern universities operate, budgetary struggles seem to be limiting the ability of some political science departments to devote any effort toward preparing their students for the job market. We discovered that $4 \%$ of our open-ended survey participants stated that they simply do not have the resources to concentrate on career preparation within their respective departments. One respondent affirmed that his/her department "can't do career prep because [they] can't even offer enough political science courses." Another respondent suggested that career preparation is a "desirable goal," but his/her department has "too few faculty and too many general education responsibilities to take on the additional responsibility of career preparation." This distress over budgetary limitations mirror concerns that have been raised over reforms to curriculum structure outside of career preparation (Ishiyama 2005).

In addition to presenting our descriptive survey results, we also wanted to determine how career preparation does (or does not) vary by the type of department and other university characteristics. To examine factors that may affect the use of career preparation activities, we created a count variable from our survey responses that indicated the number of curriculum-based career preparation activities. This variable included response from the following questions: (1) whether the department required an internship; (2) whether the department had a mentoring program; (3) whether the department required their majors to complete a resume; and (4) whether the department has some class that is at least partially focused on career preparation. Although this list is not exhaustive of all the things that could be done for career preparation, these represent activities often mentioned as important in the literature. Further, while some respondents included unique career development practices, no activities other than the ones included in our count variable were consistently reported in our open-ended responses. This count variable ranged from zero to four based on how many "yes" answers were given in the survey to each of these questions

It is important to recognize that the majority of the responding departments $(62 \%)$ reported that they did not conduct any of these activities within their majors. None of the respondents reported doing all of these activities, and only 11 departments (4\%) reported doing three out of these four activities. Given that our dependent variable (the number of career preparation activities conducted by departments) is a count variable (King 1988) and given the high number of zeros in our data, we selected a zero-inflated Poisson regression model as the best method to exam- ine variation in our observations (Long and Freese 2006). ${ }^{2}$ This method first estimates the probability that the event count is always zero using a logistic regression model (the transition stage). In our model, this would mean that a department does not conduct any of the career-building activities. In the second phase (the event state), a Poisson regression model is conducted to determine the variation in the number of events, presuming the count is not always zero (Sheingate 2006).

Because a lack of financial and human resources may present a major hurdle to some of the activities in our measure, we include control variables obtained from College Results Online to capture potential differences in resources between universities. We distinguished between public and private universities as well as university size, measured by the number of students enrolled. Because university missions differ (some likely place more emphasis on undergraduate education), we also control for department type and compare $\mathrm{PhD}$ departments to those without a $\mathrm{PhD}(\mathrm{BA}$ and MA departments). We also considered average SAT scores, with the expectation that universities with higher SAT scores may see less utility in conducting career-building activities. Another issue that could influence these activities may be the schools' geographic locations. For example, when examining internship programs, those students attending universities located in larger urban settings may have more access to internship opportunities while political and governmental internships related to political science may be less prevalent in rural settings, limiting the practicability of requiring internships. ${ }^{3}$

Table 1 presents the results of our zero-inflated Poisson regression. The second column in table 1 represents the coefficient values, the significance levels (two-tailed), and the robust standard errors in parentheses. ${ }^{4}$ In the "transition stage" equation, we see that several variables influence whether a department conducts any career preparation activities. A positive value in the transition stage indicates a higher likelihood that the dependent variable is zero (no career preparation activities), while a negative value indicates a higher likelihood of at least one career activity (that the dependent variable is not zero). The positive and statistically significant value for SAT indicates that departments from universities with higher average SAT scores of incoming freshmen are less likely to include any of the listed career preparation activities into their curricula. However, the negative and statistically significant values for BA departments ( $p<.05$, two-tailed), urban universities and public universities $(p<.10$, two-tailed) indicate that departments with these characteristics are less likely to have a value of zero for our dependent variable, or, stated differently, that they are more likely to participate in at least one career preparation activity. As expected, departments in the schools with higher SAT scores may see less utility in conducting careerbuilding activities given their universities' perceived reputations. However, BA departments are more likely to conduct some careerbuilding activities when compared to $\mathrm{PhD}$ programs, perhaps because of their more undergraduate-focused missions. The negative coefficient for the urban university variable indicates that access to more career opportunities in larger cities, such as the availability of internships, may play a role in a department's implementation of these strategies.

In the "event stage" model, a positive value indicates the likelihood of higher event counts or that a department includes more career-preparation activities. Here, we see that MA departments are more likely to conduct higher numbers of career building 
Table 1

\section{Zero-Inflated Poisson Regression Model for the Number of Career Preparation Activities}

\begin{tabular}{|c|c|}
\hline VARIABLE & $\begin{array}{c}\text { COEFFICIENT } \\
\text { (ROBUST STD. ERRORS) }\end{array}$ \\
\hline \multicolumn{2}{|l|}{ Event Stage } \\
\hline \multirow[t]{2}{*}{ Urban University } & -.275 \\
\hline & (.18) \\
\hline \multirow[t]{2}{*}{ University Size } & .000 \\
\hline & $(.00)$ \\
\hline \multirow[t]{2}{*}{ BA Department } & .652 \\
\hline & $(.41)$ \\
\hline \multirow[t]{2}{*}{ MA Department } & $.752^{* *}$ \\
\hline & (.38) \\
\hline \multirow[t]{2}{*}{ Public University } & -.225 \\
\hline & (.24) \\
\hline \multirow[t]{2}{*}{ SAT Average } & -.000 \\
\hline & $(.00)$ \\
\hline \multirow[t]{2}{*}{ Constant } & -.765 \\
\hline & 1.09 \\
\hline \multicolumn{2}{|l|}{ Transition Stage } \\
\hline \multirow[t]{2}{*}{ Urban University } & $-16.66^{*}$ \\
\hline & $(9.52)$ \\
\hline \multirow[t]{2}{*}{ University Size } & .000 \\
\hline & $(.00)$ \\
\hline \multirow[t]{2}{*}{ BA Department } & $-23.909 * *$ \\
\hline & $(11.91)$ \\
\hline \multirow[t]{2}{*}{ MA Department } & -1.709 \\
\hline & (1.70) \\
\hline \multirow[t]{2}{*}{ Public University } & $-37.496^{*}$ \\
\hline & (21.19) \\
\hline \multirow[t]{2}{*}{ SAT Average } & $.113^{* *}$ \\
\hline & $(.06)$ \\
\hline \multirow[t]{2}{*}{ Constant } & $-113.940^{* *}$ \\
\hline & (57.12) \\
\hline $\mathrm{N}$ & 279 \\
\hline Wald Chi-Square & $12.75^{* *}$ \\
\hline
\end{tabular}

activities than PhD departments, even after controlling for other factors. 5 This is displayed by the positive coefficient, which is statistically significant $(p<.05)$ in the event stage model. When we investigate this more closely, we discover that there were no $\mathrm{PhD}$ departments that had a required internship or a required resume for political science majors. There were no statistically significant differences in the number of career-building activities based on whether the university was located in an urban area, the university's size, SAT averages, or distinctions between public and private universities. Therefore, university factors, such as SAT averages, location, and whether the university is a public institution influence whether the department offers any of these activities.

\section{CONCLUSION AND DISCUSSION}

Our findings suggest several broad themes regarding departmental efforts to prepare their undergraduate students for the job market. The first theme is that there is no "one size fits all" approachmany departments employ several different methods of career preparation simultaneously. Second, and more importantly, the question responses suggest that voluntary internships and traditional faculty advising still dominate departmental approaches to this task. Our results indicate that only a small number of political science departments are implementing specific career preparation models designed to meet the needs of their students. Although students can get valuable input and experiences from voluntary internships and faculty advising, we question whether these activities are sufficient in preparing students to enter a modern job market that emphasizes pragmatism by arguably undervaluing the skills of liberal arts majors in comparison to more "desirable" students with technical skills or pre-professional degrees.

As professors, we play a vital role in helping students understand the value of a political science degree and a liberal arts education more generally. Professors can create assignments and activities that simulate the types of activities graduates will perform in a variety of different careers. A standard research report can be cast as a "white paper" aimed to help key decision-makers evaluate the effectiveness of a specific policy challenge. Professors are also well positioned to help students articulate and market the skills they learn both inside and outside the classroom. Most university career centers have professionals to help students in this area, but faculty should also play a role in preparing students for life after graduation. Political science professors know the specific learning objectives from their courses and can help students articulate these outcomes to potential employers.

Certainly, hiring trends indicate that employers look to "expedite the transition of these recruits from the classroom to the workplace while minimizing costs associated with the transition" (Koc 2010, 16). In turn, this has "led employers to place greater emphasis on the development of specific job-related skills in the educational backgrounds of their recruits" (Koc 2010, 16). This finding suggests that a focus on the "practical" side of career preparation in political science, and indeed in all liberal arts disciplines, will prove increasingly necessary if our graduates are to have a full array of employment opportunities open to them. Many of our survey respondents, in fact, seem to acknowledge this new employment reality, at least implicitly, by indicating that their departments were in the process of revamping their career preparation efforts in the face of a continually contracting job market.

How are political science departments responding to this new environment? First, curricular changes seem to be an important strategy. In fact, in their open-ended responses, many of our survey respondents indicated efforts to create new career-oriented classes for their majors by using a combination of capstone/ senior seminar, portfolio, introduction to political science, or other type of required career preparation class for their students. Survey participants suggest that the professors leading these types of classes spend a significant amount of instructional time aiding students in creating and refining resumes, conducting practice interviews, and developing other job-related skill sets, all of which should be relevant to future employment efforts.

Other curriculum-related initiatives emerge as a response to the criticism that political science programs fail to help students 
develop practical job skills. In part, this emphasis seems to operationalize itself as a required internship, which serves as a departure from voluntary internships. Experiences in other disciplines suggest that, if done with ample time and effort in personal reflections and faculty supervision, internships can be rewarding (Danzger 1988). Some of the more novel approaches may also include the creation of a mandatory service learning course and a class dedicated to developing professional campaign skills. Additionally, and in the tradition of developing more marketable skills, one department chair indicated that his/her political science program runs a five-year joint degree program with the business school, in which a student can earn both a BA in political science and an MBA. Advising-related career preparation initiatives are gaining ground as well. For instance, one of our surveyed departments created a mandatory career and professional development plan, the implementation of which will involve collaboration between students and advisers. The template for the plan was "designed by [the] career center and then customized by department faculty," and will be used in both "department and individual level advising."

Even voluntary internships are undergoing a transformation in some of the surveyed departments. Perhaps the most innovative approach is a structured "Living Leadership" program in which a faculty member accompanies students to either the state or national capital during the spring semester. The program then asks students to live together in a residential setting, complete a political internship, and take a course with the accompanying professor. According to the department chair, the program "has led to employment for about half of the participants before they even complete their degrees." At another university, the political science department maintains a fund for financing internships either in Washington, DC, local law offices, or overseas. This fund is "sufficient to finance study programs to supplement preparation for careers-ex. language programs or specialized courses" not offered by the department itself. Both of these approaches to internships, of course, require a regular source of funding, and although the current economic environment may render moot for the moment the impetus for these types of programs, such creative approaches merit future consideration if and when budgets improve.

Finally, and perhaps most importantly, we need to develop ways to determine the effectiveness of different career preparation strategies. One study evaluating the employment success of recent college graduates found that work related to career goals was the "only experience of universal effectiveness" (Sagen, Dallam, and Laverty 2000, 753). Knowing the relative effectiveness of career-focused curriculum, career-focused advising, and social media use will put faculty in a better position to best prepare students for the challenges of life after graduation.

\section{NOTES}

1. We use the term "department chair" to refer to both department heads and department chairs.

2. The use of this model was justified by the Vuong test, which was statistically significant $(z=2.32 ; p=0.01)$, indicating that the zero-inflated Poisson is preferable to the Poisson regression (Long and Freese 2006). We also conducted a standard Poisson regression and an ordered logit model that produced very similar results.

3. Similar to prior studies (Ishiyama 2005), we initially planned to include a student-faculty ratio variable for each political science department. However, we did not include this control in our final model because too few respondents answered our survey questions about faculty membership and the estimated number of majors. When we included this variable in one of our preliminary models, however, it did not achieve statistical significance.

4. The statistical significance levels did not change whether we used standard or robust standard errors. We report the models with robust standard errors as these assist in adjusting for potential heterogeneity in the model (White 1982).

5. Regardless of which department type (BA, MA, PhD) was used in the model or which department was excluded as the omitted reference category, $\mathrm{PhD}$ departments consistently displayed a lower probability of conducting career preparatory activities.

\section{REFEREN C E S}

American Political Science Association. 2003. Careers and the Study of Political Science: A Guide for Undergraduates, 6th ed, Washington, DC: American Political Science Association.

Breuning, Marijke, Paul Parker, and John T. Ishiyama. 2001. "The Last Laugh: Skill Building through a Liberal Arts Political Science Curriculum.” PS: Political Science and Politics 34: 657-61.

Conklin, Kristin. 2011. "Embracing Our Demographic Future: The True Test for Higher Education.” Inside Higher Education, http://www.insidehighered.com/ blogs/statehouse_test, March 1.

Danzger, M. Herbert. 1988. "Undergraduate Education in Sociology as Career Training: The Case for an Internship Program." Teaching Sociology 16: 41-48.

Humphreys, Debra. 2006. Making the Case for Liberal Education: Responding to Challenges. Washington, DC: Association of American Colleges and Universities.

Ishiyama, John. 2005. "Examining the Impact of the Wahlke Report; Surveying the Structure of Political Science Curricula at Liberal Arts and Science Colleges and Universities in the Midwest." PS: Political Science and Politics 38: 71-75.

Ishiyama, John, Marijke Breuning, and Linda Lopez. 2006. "A Century of Continuity and (Little) Change in the Undergraduate Political Science Curriculum." American Political Science Review 100: 659-65.

Ishiyama, John, and Stephen Hartlaub. 2003. "Sequential or Flexible? The Impact of Differently Structured Political Science Majors on the Development of Student Reasoning." PS: Political Science and Politics 36: 83-86.

King, G. 1988. "Statistical Models for Political Science Event Counts: Bias in Conventional Procedures and Evidence for the Exponential Poisson Regression Model." American Journal of Political Science 32: 838-63.

Koc, Edwin W. 2010. "NACE Research: The Liberal Arts Graduate and the College Hiring Market." NACE Journal 71 (2): 14-21.

Kuh, George D. 1995. "The Other Curriculum: Out-of-Class Experiences Associated with Student Learning and Personal Development." Journal of Higher Education 66: 123-55.

Leonard, Steven T. 1999. “'Pure Futility and Waste': Academic Political Science and Civic Education." PS: Political Science and Politics 32: 749-54.

Long, J. Scott, and Jeremy Freese. 2006. Regression Models for Categorical Dependent Variables Using Stata, 2nd ed. College Station, TX: Stata Press.

Mansfield, Harvey C. 1947. "The Major in Political Science.” American Political Science Review 41: 500-07.

Morelli, B.A. 2011. "Does the Legislature Have It Out for UI?" Iowa City PressCitizen, 〈http://www.press-citizen.com/article/20110212/NEWSo1/102120309/ Does-the-Legislature-have-it-out-for-UI $\rangle$, February 12.

Parilla, Peter F., and Garry W. Hesser. 1998. "Internships and the Sociological Perspective; Applying Principles of Experiential Learning." Teaching Sociology 26: 310-29.

Sagen, H. Bradley, Jerald W. Dallam, and John R. Laverty. 200o. "Effects of Career Preparation Experiences on the Initial Employment Success of College Graduates." Research in Higher Education 41 (6): 753-67.

Satariano, William A., and Sharon J. Rogers. 1979. "Undergraduate Internships: Problems and Prospects." Teaching Sociology 6: 355-72.

Schawbel, Dan. 2009. Me 2.o: Build a Powerful Brand to Achieve Career Success. New York: Kaplan Publishing.

Sheingate, Adam D. 2006. "Structure and Opportunity: Committee Jurisdiction and Issue Attention in Congress." American Journal of Political Science 50: 844-59.

Wahlke, John C. 1991. "Liberal Learning and the Political Science Major: A Report to the Profession." PS: Political Science and Politics 24 (1): 48-6o.

White, H. 1982. "Maximum Likelihood Estimation of Misspecified Models." Econometrica 50: 1-24.

Wright, Cheryl A., and Scott D. Wright. 1987. "The Role of Mentors in the Career Development of Young Professionals." Family Relations 36: 204-208. 